\title{
Use of an ELISPOT immunoassay to detect euphausiid predation on larval anchovy
}

\author{
Gail H. Theilacker ${ }^{1}$, Amy S. Kimball ${ }^{1}$ \& James S. Trimmer ${ }^{2}$ \\ ${ }^{1}$ National Marine Fisheries Service, Southwest Fisheries Center, 8604 La Jolla Shores Drive, La Jolla, California 92038, USA \\ ${ }^{2}$ Scripps Institution of Oceanography, University of California San Diego, La Jolla, Californía 92093, USA
}

\begin{abstract}
The ELISPOT immunoassay, where samples are spotted onto $0.45 \mu \mathrm{m}$ pore-size nitrocellulose and incubations are based on a BLOTTO/Tween system, proved satisfactory for detecting northern anchovy Engraulis mordax yolk in euphausijd Euphausia pacifica guts. Polyclonal antiserum to anchovy yolk was developed in male New Zealand rabbits. The system detected 30 nannograms purified yolk protein with 1:5000 diluted antiserum and positively identified $75 \%$ of experimentallyfed and frozen euphausiids.
\end{abstract}

\section{INTRODUCTION}

Euphausiids, copepods, amphipods, and other small Crustacea potentially prey on the earliest stages of marine fish larvae (reviewed by Hunter 1981, 1984, Brewer et al. 1984). Euphausiids, for example, co-occur in the sea with northern anchovy larvae, and in the laboratory individual euphausiids consume up to 25 larvae $d^{-1}$ (Theilacker \& Lasker 1974). Thus if this predation rate occurs in the sea, euphausiids could be responsible for an important portion of the mortality of yolk-sac anchovy larvae as well as other fish larvae. Because Crustacea macerate their prey, it is impossible to visually identify larval remains in the stomachs of wild Crustacea. Two possible solutions to this problem are to use larval eye lenses to identify the larval remains (Purcell 1984) or to use immunoassays designed to detect species-specific proteins (Boreham \& Ohiagu 1978, Calver 1984). Here we evaluate the use of an immunoassay to detect larval northern anchovy Engraulis mordax remains in euphausiid Euphausia pacifica stomachs.

Serological precipitation and agglutination reactions have been used in other predator-prey studies. Boreham \& Ohiagu (1978) reviewed and evaluated studies that used serological techniques to describe invertebrate (mainly economically important insects) predator-prey relations and predation rates. Feller et al. (1979) applied serological techniques to describe food web relations in a benthic community. These tests required large quantities of the unknown stomach samples and serum. More recently developed radioimmunoassays (RIA) (Heusser et al. 1981) and enzymelinked immunosorbent assays (ELISA) (Engvall \& Perlmann 1972) require small samples, are extremely sensitive and are quantitative. Crook \& Sunderland (1984) used ELISA to detect the ingestion of aphids by predatory spiders. We selected the solid-phase enzymelinked immunospot (ELISPOT) (Monroe 1985) because, in addition to being an ultrasensitive technique, it was the most effective procedure for assaying many small samples. We prepared a polyclonal antiserum to anchovy egg yolk proteins because previous laboratory work indicated that only yolk-sac stage larvae were vulnerable to euphausiids (Theilacker \& Lasker 1974). The sensitivity of the ELISPOT and antiserum was tested by assaying euphausiids fed yolk-sac anchovy larvae in the laboratory.

\section{METHODS}

Feeding. Euphausiids collected off the coast of California from the NOAA Ship David Starr Jordan were maintained in the laboratory at 15.5 to $16.0^{\circ} \mathrm{C}$ (Lasker \& Theilacker 1965) and fed the alga Dunaliella tertiolecta to clear their guts 24 or more $\mathrm{h}$ before a feeding test. For feeding tests, single euphausiids were placed into 250 to $750 \mathrm{ml}$ sea water containing 25 to 50 yolk-sac larvae. After euphausiids fed for 2 to $3 \mathrm{~h}$, they were frozen individually in liquid nitrogen, and larval anchovy prey remaining in the containers were counted to determine the number eaten. 
Preparation of antigen. To obtain anchovy yolk proteins for the antigen, we separated the yolk from egg membranes and vacuoles by washing freshly spawned anchovy eggs in $0.45 \mu \mathrm{m}$ filtered sea water and hand homogenizing them in $10 \mathrm{mM}$ phosphate buffer $\mathrm{pH} 7.4$ with 3 to 4 strokes in a glass tissue homogenizer on ice (R. A. Wallace pers. comm.). The solution was spun for $5 \mathrm{~min}$ in an Eppendorf microfuge $(15600 \times \mathrm{g})$. The supernatant, containing $18 \mathrm{mg} \mathrm{ml}^{-1}$ protein (method. by Lowry et al. 1951), was frozen at $-80^{\circ} \mathrm{C}$ in $500 \mu l$ aliquots for use in rabbit injection (see 'Preparation of antisera'), titre tests, and as internal standards.

Preparation of antisera. Two male New Zealand White rabbits were bled twice before immunization. The bleeds were from the central ear artery and were $7 \mathrm{~d}$ apart; each rabbit gave a total of $70 \mathrm{ml}$ blood. For these bleeds and all subsequent bleeds, we allowed blood to clot for $35 \mathrm{~min}$ in a centrifuge tube at room temperature, rung once with a glass stirring rod (Hurn \& Chantler 1980) and centrifuged at $2000 \times \mathrm{g}$ for $10 \mathrm{~min}$. We removed the serum fraction and froze it at $-80^{\circ} \mathrm{C}$ in $500 \mu$ l aliquots.

The schedule for injecting the rabbits was based on Vaitukaitus (1981) in which microgram amounts of antigen were used to produce antisera with high titre. The first injection was given $12 \mathrm{~d}$ after the second preimmune bleed. We diluted yolk preparation in $10 \mathrm{mM}$ phosphate buffer pH 7.4 and emulsified in 3 volumes Freund's complete adjuvant on ice using a Brinkmann Polytron homogenizer on low to medium speed for $15 \mathrm{~s}$. An emulsification containing $180 \mu \mathrm{g}$ yolk in $1 \mathrm{ml}$ was injected into 8 intradermal sites $\left(0.125 \mathrm{ml} \mathrm{site^{-1 } )}\right.$ on a shaved region of each rabbit's back adjacent to the spine. The first antiserum was collected on Day 24 Rabbits were 'boosted' with $0.5 \mathrm{ml}$ emulsification containing $45 \mu \mathrm{g}$ yolk in Freund's incomplete adjuvant on Day 44 and again 6 mo later. The final bleed was taken 10 mo after the first injection.

ELISPOT. We placed individual euphausiids stored at $-80^{\circ} \mathrm{C}$ in $15 \mu \mathrm{l}$ extraction buffer $(10 \mathrm{mM}$ Tris hydroxymethyl aminomethane hydrochloride [Tris- $\mathrm{HCl}$ ] pH 7.4, $1 \mathrm{mM}$ ethylenediaminetetraacetic acid [EDTA]) on a clean microscope slide and, using a dissecting microscope at $6 \times$ to $25 \times$, dissected the euphausiid stomach, hindgut, hepatopancreas and mouthparts. These tissues were teased apart and extracted in the buffer prior to dotting $10 \mu$ of this protein extract onto nitrocellulose paper $(0.45 \mu \mathrm{m}$ pore size). We have stored these protein extracts on the nitrocellulose for up to $4 \mathrm{~d}$ at $3^{\circ} \mathrm{C}$ with no loss in activity. Dotted nitrocellulose was blocked by incubating $1 \mathrm{~h}$ in $25 \mathrm{ml}$ BLOTTO/Tween $15 \%$ dry nonfat milk in $0.45 \mu \mathrm{m}$ filtered sea water; $0.01 \%$ Antifoam $A_{i} 0.0001 \%$ merthiolate; $0.05 \%$ polyoxyethylene [20] sorbitan monolaurate [Tween 20]; Johnson et al. 1984). This was followed by $1 \mathrm{~h}$ incubation in the primary antibody, 1:5000 rabbit serum (pre-immune or immune) diluted in $5 \mathrm{ml}$ BLOTTO/Tween. A series of 3 detergent washes followed the primary antibody incubation (first wash $[3 \times 10 \mathrm{~min}], 0.5 \mathrm{M} \mathrm{NaCl} ; 10 \mathrm{mM}$ Tris-HCl, $\mathrm{pH}$ 8.2; $0.5 \%$ Nonidet $\mathrm{P}-40 ; 1 \mathrm{mM}$ EDTA; $1 \mathrm{mg} \mathrm{ml}^{-1}$ nonfat milk; $0.1 \%$ Lauryl sulfate [SDS]; second wash $[3 \times 10 \mathrm{~min}]$, substitute $0.15 \mathrm{M} \mathrm{NaCl}$ for $0.5 \mathrm{M}$ in first wash and eliminate milk; third wash $[3 \times 10 \mathrm{~min}]$, equivalent to second wash without SDS; Trimmer et al. 1985). After the washes the samples were blocked in $3 \%$ normal goat serum in $5 \mathrm{ml}$ BLOTTO/Tween for $20 \mathrm{~min}$ and then incubated for $1 \mathrm{~h}$ with $3 \%$ normal goat serum and the secondary antibody, 1:1000 Goat Anti-rabbit conjugated alkaline phosphatase (Blake et al. 1984), in $5 \mathrm{ml}$ BLOTTO/Tween. After incubation with the secondary antibody, the samples were washed $4 \times 10 \mathrm{~min}$ in BLOTTO/Tween followed by a $10 \mathrm{~min}$ wash in $0.15 \mathrm{M}$ Tris-Base $\mathrm{pH}$ 9.6. Reactions were done using $47 \mathrm{~mm}$ diameter nitrocellulose filters in beakers on a shaker. Each assay was run using at least one $5 \mu$ l spot of anchovy yolk protein $(0.03 \mu \mathrm{g}$ to $1 \mu \mathrm{g}$ per $5 \mu \mathrm{l}$ spot) and the extract of one starved euphausid control dotted on the nitrocellulose as internal standards for the pre-immune and immune sera.

The alkaline phosphatase activity was visualized on the nitrocellulose with a histochemical phosphatase stain (1 mg 5-bromo-4-chloro-3-indolyl phosphate dissolved in dimethyl formamide; $2 \mathrm{mg}$ nitro blue tetrazolium dissolved in $0.15 \mathrm{M}$ Tris-Base $\mathrm{pH} 9.6 ; 4 \mathrm{mM}$ $\mathrm{MgCl}_{2}$; brought to $20 \mathrm{ml}$ with $0.15 \mathrm{M}$ Tris-Base $\mathrm{pH} 9.6$; Blake et al. 1984, Knecht \& Dimond 1984). A positive reaction was a blue/black color and the color intensity corresponded to the amount of yolk protein present. All chemicals used were of highest quality.

\section{RESULTS AND DISCUSSION}

Titre of the antiserum increased 12 times after the second injection and an additional 3 times after the third injection. The final antiserum diluted 1:20000 detected $0.1 \mu \mathrm{g}$ yolk protein. We routinely used a 1:5000 dilution which detected $0.03 \mu \mathrm{g}$ yolk protein. Undiluted sera were stable at $3{ }^{\circ} \mathrm{C}$ for at least 1 mo (no azide or merthiolate present).

Antisera harvested early in the experiment are believed to be more specific (yielding fewer crossreacting antibodies) than antisera harvested later in the experiment (Vaitukaitus 1981); we found no difference in nonspecific binding to euphausiid muscle between antisera collected over $10 \mathrm{mo}$. To determine the specificity of the antisera to anchovy yolk proteins, we tested various potential euphausid foods for crossreactions. The final antisera did not react with the 
algae Gymnodinium splendens, Dunaliella sp., Monochrusis sp., the copepod Tigriopus californicus, eggs of the red crab, Pleuroncodes, and eggs of the sea urchin, Strongylocentrotus purpuratus. The serum also did not cross-react with white sea bass Atactoscion nobilis yolk protein but did cross-react with egg yolk from the sardine Sardinops sagax, indicating that the serum may not discriminate between clupeoid yolk proteins in general. This cross-reaction could perhaps be removed by absorption (Boreham \& Ohiagu 1978). As live fish eggs become available, we will determine the ability of the antibody to discriminate between teleosts. In all tests the pre-immune controls were nonreactive.

Proteins from the yolk preparation and similar preparations of developing anchovy eggs and larvae, Days 2 to 6 , were analysed by SDS-polyacrylamide gel electrophoresis (SDS-PAGE, $10 \%$; Maizel 1971). Seven Coomassie staining bands of $\mathrm{Mr}=16700,18200$, $28200,30300,72900,80700$ and 91200 were present in the yolk preparation but not in post yolk-sac larvae. Proteins from the yolk-sac preparation and the post yolk-sac larvae, separated on $10 \%$ SDS-PAGE, were transferred to nitrocellulose paper (Towbin et al. 1979) and reacted with immune and pre-immune serum using the incubations and washes of the ELISPOT procedure. Three yolk bands $(\mathrm{Mr}=72900,80700$ and $91200)$ reacted with the first antisera; the antisera did not react with the non-yolk anchovy proteins. The ELISPOT revealed that the reactivity of the yolk proteins with the antisera was maintained during egg and larval development.

Yolk preparations were stable, maintaining their reactivity for at least 1 mo at $3{ }^{\circ} \mathrm{C}$ when stored in concentrated forms. Ability of buffer systems to maintain ingested yolk protein stability was determined by incubating $10 \mu \mathrm{g}$ of yolk protein with buffer homogenates of the euphausiid stomach and hepatopancreas for 15 and $60 \mathrm{~min}$ at $12{ }^{\circ} \mathrm{C}$. These tests revealed that the Tris/EDTA extraction buffer maintained yolk protein stability better than millipore filtered sea water or phosphate-buffered saline $\left(0.01 \mathrm{M} \quad \mathrm{NaH}_{2} \mathrm{PO}_{4} \cdot \mathrm{H}_{2} \mathrm{O}\right.$, $0.15 \mathrm{M} \mathrm{NaCl}, \mathrm{pH} \mathrm{7.2)}$ and that protease inhibitors (phenyl methyl sulfonyl fluoride, soybean trypsin inhibitor) and competitors (benzamidine, bovine serum albumin; BSA) did not increase stability.

When testing RIA and ELISA, we found that we were losing samples from the plastic wells during the washes. This did not appear to be a problem in the case of nitrocellulose paper.

To eliminate nonspecific binding of the antiserum to the muscle protein of starved euphausids in the ELISPOT assays we tried dissecting the digestive tissues from the animal. Dissecting decreased the cross-reaction obtained by testing whole animal extracts. We also reduced this unwanted reaction to a negligible level by using the BLOTTO technique of Johnson et al. (1984) to block nonspecific protein binding sites on the nitrocellulose, to carry the antibodies, and as the washing solution instead of using BSA or gelatin. The addition of the detergent Tween-20 to the BLOTTO buffer, a series of rigorous washes (high-salt, low-salt detergent washes) and an incubation in $3 \%$ NGS (see ELISPOT) also significantly reduced the background. Dialyzing the antisera in sea water did not improve the assay.

Initially we used horseradish peroxidase as the conjugate (GAR/HRP; goat antirabbit horseradish peroxidase) for the secondary antibody with Aminoethyl-carbazole as the substrate (Podell \& Vaquier 1984). We found that extracts from euphausiid preparations gave the same pink/brown color (astaxanthin pigment; Mauchline \& Fisher 1969) when dotted onto the nitrocellulose as the final visualization of the GAR/ HRP reaction. Solvent extractions of the pigment prior to ELISPOT were unsatisfactory because the lipophilic yolk proteins were also extracted. Visualization of an alkaline phosphatase (GAR/AP) conjugate of the secondary antibody produced a blue/black color that is easily differentiated from the pigment spot.

Using ELISPOT we tested 56 laboratory-fed euphausiids for the presence of anchovy yolk and of these 42 animals were positive. No response may be due in part to loss of yolk protein from the yolk sac when the euphausiid grasps and macerates the larva. On the other hand, gastric evacuation rates of larvae in euphausiid stomachs may be very high, with complete evacuation occurring within the experimental feeding period. Preliminary experiments show that yolk protein is digested in less than $4 \mathrm{~h}$. We calculated that the stomach of a $20 \mathrm{~mm}$ euphausid which consumed one yolk-sac anchovy could contain as much as $1.8 \mu \mathrm{g}$ anchovy yolk protein (volume of a euphausiid stomach is about $0.06 \mathrm{~mm}^{3}$; a full stomach holds $60 \mu \mathrm{g}$ wet weight or about $6 \mu \mathrm{g}$ dry weight for prey containing $90 \%$ water; the dry weight of a Day 2 yolk-sac anchovy is $21 \mu \mathrm{g}$ and $30 \%$ of the dry weight is yolk protein; $30 \%$ of the maximum euphausid stomach contents $[6 \mu \mathrm{g}$ ] is $1.8 \mu \mathrm{g}$ ) but the ELISPOT assay rarely detected more than $0.3 \mu \mathrm{g}$ in stomachs of the euphausiids fed in the laboratory. Thus it appears the reactivity of the antisera to anchovy yolk proteins may be reduced in vivo.

The ELISPOT assay is a quantitative technique, although application of the assay in the field cannot be quantified here because the absolute amount of yolk in an individual anchovy decreases with age and because the reactivity of the yolk protein to the antisera apparently decreases in vivo. However, we can estimate the impact of euphausiid predation on larval anchovy by 
determining the positive euphausiid antigen-antibody reactions and adjusting for their size-specific feeding rates, their temperature-specific digestion time, their size-specific abundance, and relating the estimated extent of predation to the abundance of larval anchovy.

A proposed predation study, part of an integrated study of the northern anchovy habitat off southern California, will yield quantitative information on the total number of larval fish taken, the proportion of anchovy larvae, and the size-specific abundance of Euphausia pacifica. Much additional information has been published by Brinton $(1962,1967,1976$, Brinton \& Wyllie 1976) on the seasonal abundance and vertical distribution of all E. pacifica growth stages in the California Current. Theilacker \& Lasker (1974) reported on laboratory studies of size-specific feeding rates of $E$. pacifica on larval anchovy, and the immunoassay will yield information on the presence of anchovy yolk protein in E. pacifica guts that can be related to their size. Preliminary experiments show that the yolk protein is labile; activity cannot be detected in euphausiid guts after a digestion time of $4 \mathrm{~h}$. The $2.5 \mathrm{~mm}$ mesh net used to collect the euphausiids does not catch potential euphausiid prey, thus avoiding the possibility of euphausiids feeding while in the net. Nicol (1984) showed that feeding in the net by the euphausiid Meganyctiphanes norvegica caused significant error. Unfortunately, we have the problem of unknown cross-reactions with yolk from other larval fish. However, in the area that we intend to study off the coast of California, northern anchovy larvae are the most abundant larval fish, comprising about $80 \%$ of the total larval fish taken in recent annual surveys (Loeb et al. 1983, H. G. Moser pers. comm.).

Application of an immunoassay in the field to assay the gut contents of small, predatory Crustacea requires an extremely sensitive technique because of the small sample size and the probability of reduced antisera reactivity with digested yolk protein. The highly sensitive ELISPOT assay measured nannogram quantities of anchovy yolk protein in euphausiid guts. In addition, ELISPOT is easy to perform, taking about $6 \mathrm{~h}$ to complete. The number of predators that can be tested in a day is limited by the number of animal dissections that can be performed in a day. A stomach dissection takes about 6 min, and stomach contents spotted on nitrocellulose can be stored in the refrigerator up to $4 \mathrm{~d}$. possibly longer, with no loss in activity. Thus the ELISPOT assay could be applied to large-scale field studies to provide information on predation mortality of larval fishes that is needed to refine recruitment estimates.

For interested persons, antibody is available from the senior author.
Acknowledgements. We would like to thank Marlene Johnson for her capable assistance with the feeding experiments and the immunoassays. Steve Gardiella and Larry Gustafson taught us procedures for immunizing and bleeding rabbits. Don Seibert assisted with some of the bleeds, Jack Metoyer, Richard Methot. George Hemingway and others collected Live euphausids for us, and Roger Leong spawned the anchovies. John Hunter and anonymous reviewers reviewed the manuscript and made constructive comments

\section{LITERATURE CITED}

Blake, M. S., Johnston, K. H., Russell-Jones, G. J., Gotschlich, E. C. (1984). A rapid, sensitive method for detection of alkaline phosphatase-conjugated anti-antibody on Western blots. Analyt. Biochem. 136: 175-179

Boreham, P. F. L., Ohiagu, C. E. (1978). The use of serology in evaluating invertebrate prey-predator relationships: a review. Bull. ent. Res. 68: 171-194

Brewer, G. D., Kleppel, G. S., Dempsey, M. (1984). Apparent predation on ichthyoplankton by zooplankton and fishes in nearshore waters of southern California. Mar. Biol. 80 : $17-28$

Brinton, E. (1962). The distribution of Pacific euphausids. Bull. Scripps Instn Oceanogr., Univ. Calif. 8: 51-270

Brinton, E. (1967). Vertical migration and avoidance capabi]ity of euphausiids in the California Current. Limnol. Oceanogr. 12: 451-483

Brinton, E. (1976). Population biology of Euphausia pacifica off southern CaLifornia. Fish. Bull. U. S. 74: 733-762

Brinton, E., Wyllie, J. G. (1976). Distributional atlas of euphausiid growth stages off southern California, 1953 through 1956. CalCOFI (Calif. coop. ocean. Fish. Invest.) Atlas No. 24

Calver, M. C. (1984). A review of ecological applications of immunological techniques for diet analysis. Aust. J. Ecol. 9: $19-25$

Crook, N. E., Sunderland, K. D. (1984). Detection of aphid remains in predatory insects and spiders by ELISA. Ann. appl. Biol. 105: 413-422

Engvall, E., Perlmann, P. (1972). Enzyme-linked immunosorbent assay, ELISA. J. Immunol. 109: 129-135

Feller, R. J., Taghon, G. L., Gallagher, E. D., Jumars, P. A. (1979). Immunological methods for food web analysis in a soft-bottom benthic community. Mar. Biol. 54: 61-74

Heusser, C. H., Stocker, J. W., Gisler, R. H. (1981). Methods for bindıng cells to plastic: Application to solid phase immunoassays for cell-surface antigens. Meth. Enzymol. 73: $406-417$

Hunter, J. R (1981). Feeding ecology and predation of marine fish larvae. In: Lasker, R. (ed.) Marine fish larvae: morphology, ecology, and relation to fisheries. University of Washington, Seattle, p. 33-77

Hunter, J. R. (1984). Inferences regarding predation on the early life stages of cod and other fishes. In: The propagation of cod, Gadus morhua L. Flodevigen Rapp. 1: 533-562

Hurn, A. L., Chantler, S. M. (1980). Production of reagent antibodies. Meth. Enzymol. 70: 104-142

Johnson, D. A., Gautsch, J. W., Sportsman, J. R., Elder, J. H. (1984). Improved technique utilizing nonfat dry milk for analysis of proteins and nucleic acids transferred to nitrocellulose. Gene. Anal. Techn. 1. 3-8

Knecht, D. A., Dimond, R. L. (1984). Visualization of antigenic proteins on Westem blots. Analyt. Biochem. 136: 180-184

Lasker, R., Theilacker, G. H. (1965). Maintenance of 
euphausiid shrimps in the laboratory. Limnol. Oceanogr. 10: $287-288$

Loeb, V. J., Smith, P. E., Moser, H. G. (1983). Ichthyoplankton and zooplankton abundance patterns in the California Current area, 1975. CalCOFI Rep. XXIV: 109-151

Lowry, O. H., Rosebrough, N. J., Farr, A. L., Randall, R. J. (1951). Protein measurement with the Folin phenol reagent. J. biol. Chem. 193: 265-275

Maizel, J. V. (1971). Polyacrylamide gel electrophoresis of viral proteins. Meth. Virol. 5: 179-246

Mauchline, J., Fisher, L. R. (1969). The biology of euphausiids. In: Russell, F. S., Yonge, M. (ed.) Advances in marine biology, Vol. 7. Academic Press, London

Monroe, D. (1985). The solid-phase enzyme-Lnked immunospot assay: current and potential applications. Bio. Techn. 3: $222-229$

Nicol, S. (1984). Cod end feeding by the euphausiid Meganyctiphanes norvegica. Mar. Biol. 80: 29-33

Podell, S. B., Vacquier, V.D. (1984). Inhibition of the sea urchin sperm acrosome reaction by antibodies directed against two sperm membrane proteins: characterization and mechanism of action. Expl. Cell Res. 155: 467-476

Purcell, J. E. (1984). Predation on fish larvae by Physalia physalis, the Portuguese man of war. Mar Ecol. Prog. Ser. 19: 189-191

Theilacker, G. H., Lasker, R. (1974). Laboratory studies of predation by euphausiid shrimps on fish larvae. In: Blaxter, J.H.S. (ed.) The early life history of fish. SpringerVerlag, Berlin, 287-299

Towbin, H., Staehlin, T., Gordon, J (1979). Electrophoretic transfer of proteins from polyacrylamide gels to nitrocellulose sheets: Procedure and some applications. Proc. natn Acad. Sci. USA. 76: 4350-4354

Trimmer, J. S., Trowbridge, I. S., Vacquier, V. D. (1985). Monoclonal antibody to a membrane glycoprotein inhibits the acrosome reaction and associated $\mathrm{Ca}(2+)$ and $\mathrm{H}(+)$ fluxes of sea urchin sperm. Cell 40:697-703

Vaitukaitus, J. L. (1981). Production of antisera with small doses of immunogen: multiple intradermal injections. Meth. Enzymol. 73: 46-52

This article was submitted to the editor; it was accepted for printing on February 21, 1986 